\title{
Karakteristik Morfologi, Produksi dan Nilai Nutrisi Beberapa Tanaman Pakan Lokal di Sumatera Utara
}

\author{
(Morphology Characteristic, Production and Nutritive Value of Several Local \\ Forages in North Sumatera)
}

Sirait J, Simanihuruk K, Syawal M

Loka Penelitian Kambing Potong, Sei Putih, PO Box 1 Galang 20585

juniarsirait96@yahoo.com

\begin{abstract}
The research aims was to identify and study on morphology, production, and nutritive value of several local forages resources in North Sumatra. The study had been carried out in May till December 2015. The method of this research was survey at four districts in North Sumatera. Four species among 11 species of local forages resources those were found on survey planted at Sei Putih field trial were selected by it's growth, nutritive value, and palatability criterion. Parameter recorded were plant height, number of branches, production and nutritive value. The experiment was arranged in completely randomized designed consisting of four species of forages and five replications. The results of experiment showed that Tithonia diversifolia (Mexican flower) had the best growth compared to Clibadium surinamense L, Hibiscus rosa-sinensis, and Polysciac fruticosa (L) Harms. Three months after planting T. diversifolia had $157.7 \mathrm{~cm}$ of average plant height (while other three species were only $118.0 ; 52.1$; and $15.9 \mathrm{~cm}$ respectively), average number of branch was 57.6 and average fresh production was $1,779.3 \mathrm{~g} /$ plant. Crude protein content of $C$. surinamense, $T$. diversifolia, $H$. rosa-sinensis, and $P$. fruticosa were $25.12 ; 19.56 ; 11.54$; and $22.37 \%$, respectively on the first harvest, while on the second harvest were $18.19 ; 18.88 ; 11.20$; and $19.25 \%$. Based on this results it was concluded that $T$. diversifolia and $C$. surinamense were potential to be used as goat feed.
\end{abstract}

Key Words: Morphology Characteristic, Production, Nutritive Value, Local Forage Resources

\begin{abstract}
ABSTRAK
Penelitian ini bertujuan untuk mengidentifikasi tanaman pakan lokal dan mempelajari karakteristik morfologi, produksi dan nilai nutrisi beberapa pakan lokal yang ada di Sumatera Utara. Penelitian dilakukan pada bulan Mei-Desember tahun 2015. Penelitian ini menggunakan metode survei yang dilakukan di empat kabupaten di Sumatera Utara. Sebanyak empat dari 11 spesies hasil survei yang ditanam di kebun percobaan Sei Putih diseleksi berdasarkan pertumbuhan, nilai nutrisi dan palatabilitasnya untuk kambing. Parameter yang diamati adalah tinggi tanaman, jumlah cabang, produksi dan nilai nutrisi. Rancangan penelitian menggunakan RAL terdiri atas empat spesies tanaman dengan lima ulangan. Hasil penelitian menunjukkan tanaman pakan bunga hirang (Tithonia diversifolia) memiliki pertumbuhan terbaik dibandingkan dengan bunga putih (Clibadium surinamense L), kembang sepatu (Hibiscus rosa-sinensis) dan NN (Polysciac fruticosa $\mathrm{L}$ Harms). Pada umur tiga bulan T. diversifolia memiliki rata-rata tinggi tanaman 157,7 cm (sementara tiga tanaman lainnya masing-masing 118; 52,1; dan 15,9 cm) dan jumlah cabang 57,6 dengan produksi segar 1.779,3 g/tanaman. Kandungan protein kasar bunga putih, bunga hirang, NN dan kembang sepatu pada panen pertama berturut-turut 25,12; 19,56; 11,54; dan 22,37\% dan pada panen kedua masing-masing 18,19; 18,88; 11,20; dan 19,25\%. Berdasarkan data morfologi, produksi dan kandungan protein kasar bunga putih dan bunga hirang potensial dimanfaatkan untuk pakan kambing.
\end{abstract}

Kata Kunci: Karakteristik Morfologi, Produksi, Nilai Nutrisi, Tanaman Pakan Lokal 


\section{PENDAHULUAN}

Target pemerintah untuk mencapai swasembada daging memerlukan banyak strategi yang harus dilakukan, salah satunya melalui pengembangan ternak kambing dengan penyediaan tanaman pakan yang memiliki produksi maupun nilai nutrisi yang tinggi. Peningkatan produksi ternak ruminansia akan berhasil jika ketersediaan pakan hijauan sebagai sumber pakan dapat dipenuhi secara kualitas dan kuantitas secara berkesinambungan.

Keanekaragaman hayati yang terdapat di alam Indonesia merupakan kekayaan alam yang harus dijaga dan dilestarikan. Sumber daya genetik tanaman (SDGT) baik tanaman pertanian maupun hijauan pakan perlu mendapat perhatian serius dalam penanganannya agar terjaga keletariannya dan tidak punah. Beberapa tanaman pakan ternak (TPT) yang masuk dalam daftar traktat internasional antara lain: Pueraria phaseoloides, Andropogon gayanus dan Dactylis glomerata (Balitbangtan 2004). Tanaman pakan ternak lokal ini sudah teruji secara alami dan dapat beradaptasi pada berbagai kondisi iklim serta tersebar di beberapa wilayah di Indonesia. Tahap awal penelitian ini dilakukan melalui survey di empat kabupaten di Sumatera Utara dalam rangka mengidentifikasi TPT tersebut. Hasil survey ditemukan empat spesies tanaman yang memiliki pertumbuhan dan nilai nutrisi yang bagus serta memiliki palatabilitas yang tinggi. Keempat spesies diuji tanam di Kebun Percobaan Sei Putih. meliputi: (1) Tithonia diversifolia dikenal dengan nama umum Mexican sunflower dan di Indonesia disebut sebagai bunga hirang. Dapat tumbuh sepanjang tahun dalam berbagai kondisi iklim, idealnya dengan curah hujan 1.000-2.000 $\mathrm{mm}$ pada suhu berkisar $15-31^{\circ} \mathrm{C}$. Biji tanaman T. diversifolia ini menyebar ke berbagai tempat terbawa oleh angin, air maupun oleh binatang (Wikipedia 2017a); (2) Bunga putih (Clibadium surinamense L) dikenal dengan nama umum Jackass breadnut, tumbuh secara liar namun ada juga yang dibudidayakan. Daun tanaman bunga putih ini berfungsi sebagai antibiotik dan digunakan untuk pengobatan gigitan ular. Merupakan tanaman perdu dan cocok ditanam bersamaan dengan Centrosema spp. sebagai penutup tanah untuk mencegah erosi (Anonimus 2017); (3) Kembang sepatu (Hibiscus rosa-sinensis) secara umum dikenal dengan nama China-rose, meskipun tidak mirip dengan mawar yang sesungguhnya. Kembang sepatu ini tergolong tanaman perdu atau pohon kecil yang dapat tumbuh hingga mencapai ketinggian 2-5 m. Batang tegak berwarna hijau kecokelatan dan bercabang. Bentuk daun oval berwarna hijau tua. Kembang sepatu memiliki bunga dengan lima buah kelopak bunga; warna bunganya beraneka ragam: putih, merah, merah muda, ungu dan oranye. Di Kepulauan Pasifik bunga kembang sepatu dimakan berupa salad (Wikipedia 2017b); (4) Polysciac fruticosa berasal dari India yang tergolong dalam famili Araliaceae dan dikenal dengan nama umum Ming Aralia. Pertumbuhan tanaman ini tergolong lambat. namun dapat mencapai ketinggian 1-2 m. Daun $P$. fruticosa berjari tiga dan berwarna hijau dengan panjang daun sekitar $10 \mathrm{~cm}$. Pemanfaatan tanaman ini secara umum adalah untuk pengobatan herbal juga tanaman ornamen. Di Thailand, daun $P$. fruticosa dimakan sebagai lalapan atau direbus dalam kari (Wikipedia 2017c). Penelitian ini bertujuan untuk mempelajari karakteristik morfologi, produksi dan nilai nutrisi dari empat spesies tanaman pakan lokal.

\section{MATERI DAN METODE}

\section{Tempat dan waktu penelitian}

Penelitian diawali dengan pelaksanaan survei di empat kabupaten di Provinsi Sumatera Utara meliputi Tobasa, Tapanuli Utara, Padang Lawas Utara dan Samosir pada 
bulan Mei dan Juni 2015 dan dilanjutkan dengan penanaman empat spesies tanaman pakan lokal di Kebun Percobaan Loka Penelitian Kambing Potong (Lolitkambing), Sei Putih, Kabupaten Deli Serdang, Provinsi Sumatera Utara.

\section{Bahan dan metode pelaksanaan kegiatan}

Penelitian dilakukan melalui survei yang dilaksanakan di empat kabupaten di Provinsi Sumatera Utara untuk mengidentifikasi 11 spesies tanaman yang merupakan sumber daya genetik (SDG) TPT lokal. Selanjutnya dari 11 spesies TPT tersebut dipilih empat spesies TPT lokal yang memiliki pertumbuhan terbaik untuk ditanam di Kebun Percobaan Sei Putih dan diteliti lebih lanjut.

Bahan tanaman yang diambil dari lokasi survei diperbanyak di polybag sebelum dipindah ke plot percobaan. Dua diantara keempat spesies yang belum diketahui nama latinnya (bunga putih dan NN) dibawa ke Pusat Penelitian Biologi LIPI untuk diidentifikasi/dideterminasi. Penanaman empat spesies tanaman pakan lokal telah dilaksanakan pada bulan Juli 2015 pada jarak tanam $1 \times 1 \mathrm{~m}$. Keempat spesies tanaman tersebut adalah bunga hirang ( $T$. diversifolia), bunga putih $(C$. surinamense $\mathrm{L})$, kembang sepatu (H. rosa-sinensis) dan NN ( $P$. fruticosa (L) Harms). Pengamatan karakter morfologi yang pertama dilakukan pada umur satu bulan, selanjutnya diamati setiap 15 hari. Peubah yang diamati untuk karakter morfologi adalah: tinggi tanaman dan jumlah cabang. Pemanenan pertama dilakukan pada umur tiga bulan dengan interval panen 60 hari. Dengan demikian ada dua kali panen yakni bulan Oktober dan Desember. Pada setiap panen diambil sampel untuk analisis kandungan nutrisi tanaman pakan.

\section{Rancangan penelitian}

Rancangan penelitian menggunakan rancangan acak lengkap dengan empat perlakuan (spesies TPT lokal) dan masing-masing lima ulangan (Gomez \& Gomez 1995), sehingga terdapat 20 petak percobaan, masing-masing petak seluas $100 \mathrm{~m}^{2}$ sehingga dibutuhkan lahan seluas $2.000 \mathrm{~m}^{2}$.

\section{Parameter yang diamati}

\section{Kandungan nutrisi 11 spesies tanaman pakan lokal}

Analisis nilai nutrisi mencakup bahan kering (BK), bahan organik, neutral detergent fiber (NDF), acid detergent fiber (ADF), energi dan kandungan nitrogen serta energi. Digunakan metode Van Soest (1991) untuk NDF, ADF dan bahan organik (Goering \& Van Soest 1970) serta prosedur Kjeldahl untuk analisis Nitrogen (AOAC 1990). Kandungan energi dianalisis menggunakan bom kalori meter.

\section{Seleksi empat spesies TPT lokal}

Kriteria pemilihan empat spesies tanaman yang akan ditanam dalam plot percobaan adalah dapat tumbuh dengan baik, disukai ternak dan nilai nutrisi (terutama kandungan protein kasar/PK) baik. 


\section{Karakteristik morfologi}

Pengamatan karakteristik morfologi keempat spesies TPT lokal mencakup tinggi tanaman dan jumlah cabang.

\section{Produksi tajuk}

Produksi segar tajuk diperoleh dengan melakukan pemotongan setinggi $10 \mathrm{~cm}$ di atas permukaan tanah, kemudian ditimbang dalam keadaan segar. Untuk mengetahui produksi bahan kering diambil sampel segar seberat $300 \mathrm{~g}$ untuk dianalisis di laboratorium nutrisi dan pakan ternak. Perhitungan bahan kering dapat diketahui melalui produksi BK keempat spesies TPT lokal ini.

\section{Analisis data}

Data yang diperoleh dianalisis secara statistik dengan sidik ragam menggunakan SAS 6.12 (SAS 1987) dan jika terdapat perbedaaan antar perlakuan maka dilanjutkan dengan Uji Duncan (Steel \& Torrie 1995). Model linier analisis keragaman pada penelitian ini adalah:

$$
Y \mathrm{ij}=\mu+\alpha \mathrm{i}+\varepsilon_{\mathrm{ij}}
$$

Yij = Nilai pengamatan pada jenis TPT ke-i dan ulangan ke-j

$\mu \quad=$ Rata-rata umum

$\alpha \mathrm{i} \quad=$ Pengaruh spesies TPT ke-i

$\varepsilon_{\mathrm{ij}} \quad=$ Pengaruh galat $(\mathrm{i}=1,2,3,4$ dan $\mathrm{j}=1,2,3,4,5)$

\section{HASIL DAN PEMBAHASAN}

\section{Nilai nutrisi tanaman pakan lokal}

Sebanyak sebelas sampel tanaman hasil survei ditanam di kebun koleksi, tiga diantaranya tidak dapat tumbuh dengan baik yakni bunga paet, balaka dan haramonting. Hasil analisis kandungan kimia kesebelas spesies tanaman pakan hasil survei disajikan dalam Tabel 1. Hasil penelitian menunjukkan bahwa kandungan PK tertinggi diperoleh pada tanaman bunga hirang $(22,31 \%)$ diikuti dengan bunga kembang sepatu $(19,65 \%)$, rumput gajah mini $(16,75 \%)$, bunga putih $(14 \%)$, NN dari Deli Serdang $(11,56 \%)$ dan bunga paet $(11,18 \%)$. Kandungan PK bunga hirang ( $T$. diversifolia) hasil survei ini masih lebih rendah dibandingkan dengan leguminosa Indigofera sp mencapai 27,61-28,05\% pada intensitas pemotongan yang berbeda (Tarigan et al. 2013). Berdasarkan kandungan PK, pertumbuhan dan tingkat kesukaan ternak, empat spesies yang dipilih untuk ditanam dalam plot percobaan adalah bunga hirang, kembang sepatu, bunga putih dan NN (Gambar 1). Rumput gajah mini atau yang dikenal dengan rumput gajah kerdil tidak terseleksi karena sudah diteliti hingga pemanfaatannya untuk kambing.

Keempat spesies tanaman pakan lokal tersebut dalam klasifikasinya berada pada kerajaan, divisi hingga kelas yang sama (Tabel 2). Bahkan bunga hirang dan bunga putih hanya berbeda pada genus dan spesies. Keempat tanaman ini tergolong pada tanaman berbiji yang menghasilkan bunga. 
Tabel 1. Kandungan nutrisi sebelas tanaman pakan hasil survei di SumateraUtara

\begin{tabular}{lrrrrrr}
\hline & \multicolumn{5}{c}{ Nilai nutrisi } \\
\cline { 2 - 5 } Nama TPT & Kadar air & Kadar abu & PK & NDF & ADF & Energi (kkal/kg) \\
\cline { 2 - 5 } & \multicolumn{2}{c}{-------------------} & $\%$ & ---------------- & \\
\hline Bunga putih & 84,95 & 9,27 & 14,00 & 69,88 & 41,47 & 4,8103 \\
Bunga hirang & 89,59 & 13,56 & 22,31 & 57,45 & 36,50 & 4,9929 \\
Rumput tolong & 77,39 & 9,85 & 8,37 & 45,71 & 32,74 & 5,5415 \\
Bunga paet & 89,72 & 11,17 & 11,18 & 34,77 & 30,37 & 4,9929 \\
Rumput gajah mini & 85,10 & 14,05 & 16,75 & 53,18 & 41,95 & 4,6880 \\
Balaka & 66,67 & 5,58 & 4,89 & 46,62 & 37,65 & 4,7404 \\
Haramonting & 61,12 & 4,44 & 4,63 & 61,92 & 40,87 & 5,3572 \\
NN (Deli Serdang) & 88,81 & 10,76 & 11,56 & 35,64 & 23,90 & 4,8704 \\
Kembang sepatu & 82,89 & 10,87 & 19,89 & 30,18 & 12,54 & 4,7810 \\
Bunga rii & 84,67 & 16,40 & 9,80 & 40,64 & 32,92 & 4,6564 \\
Bintatar & 59,83 & 19,65 & 10,44 & 46,33 & 37,51 & 4,2318 \\
\hline
\end{tabular}

Sumber: Laboratorium Lolitkambing Sei Putih (2015)

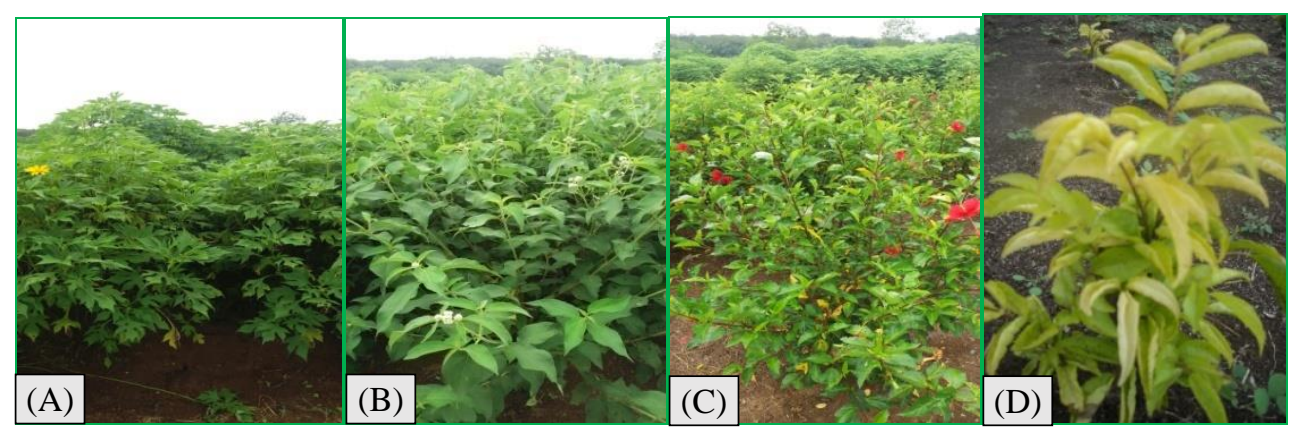
A: Bunga hirang
B: Bunga putih
C: Kembang sepatu
D: P. fruticosa

Gambar 1. Tanaman pakan lokal di Kebun Percobaan Lolitkambing

Tabel 2. Klassifikasi empat spesies tanaman pakan lokal yang ditanam

\begin{tabular}{lcccc}
\hline \multirow{2}{*}{ Klassifikasi } & \multicolumn{4}{c}{ Nama tanaman } \\
\cline { 2 - 5 } & Bunga hirang & Bunga putih & Kembang sepatu & Bunga NN \\
\hline Kingdom & Plantae & Plantae & Plantae & Plantae \\
Subkingdom & Tracheobionta & Tracheobionta & Tracheobionta & Tracheobionta \\
Super division & Spermatophyta & Spermatophyta & Spermatophyta & Spermatophyta \\
Division & Magnoliophyta & Magnoliophyta & Magnoliophyta & Magnoliophyta \\
Class & Magnoliopsida & Magnoliopsida & Magnoliopsida & Magnoliopsida \\
Subclass & Asteridae & Asteridae & Dilleniidae & Rosidae \\
Order & Asterales & Asterales & Malvales & Apiales \\
Family & Asteraceae/Compositae & Asteraceae/Compositae & Malvaceae & Araliaceae \\
Genus & Tithonia & Clibadium & Hibiscus & Polyascias \\
Species & T. diversifolia & C. surinamense & H. rosa-sinensis & P. fruticosa \\
\hline
\end{tabular}

Sumber: USDA (2017) 


\section{Karakteristik morfologi}

Hasil pengamatan menunjukkan bahwa bunga hirang ( $T$. diversifolia) memiliki pertumbuhan terbaik diantara keempat spesies yang ditanam. Hal ini terlihat dari pertambahan tinggi tanaman, panjang dan lebar daun, jumlah cabang maupun diameter batang. Untuk jumlah cabang terjadi penurunan setelah panen, namun mengalami peningkatan lagi sesuai dengan regrowth tanaman (Gambar 3).

Tinggi tanaman keempat spesies tanaman pakan lokal berbeda nyata $(\mathrm{P}<0,05)$ dan bunga hirang ( $T$. diversifolia) adalah tanaman paling tinggi dengan rata-rata tinggi tanaman pada pengamatan terkahir sebelum panen kedua setinggi 188,4 cm yang diikuti oleh bunga putih (C. surinamense L) dengan tinggi 149,7 cm.

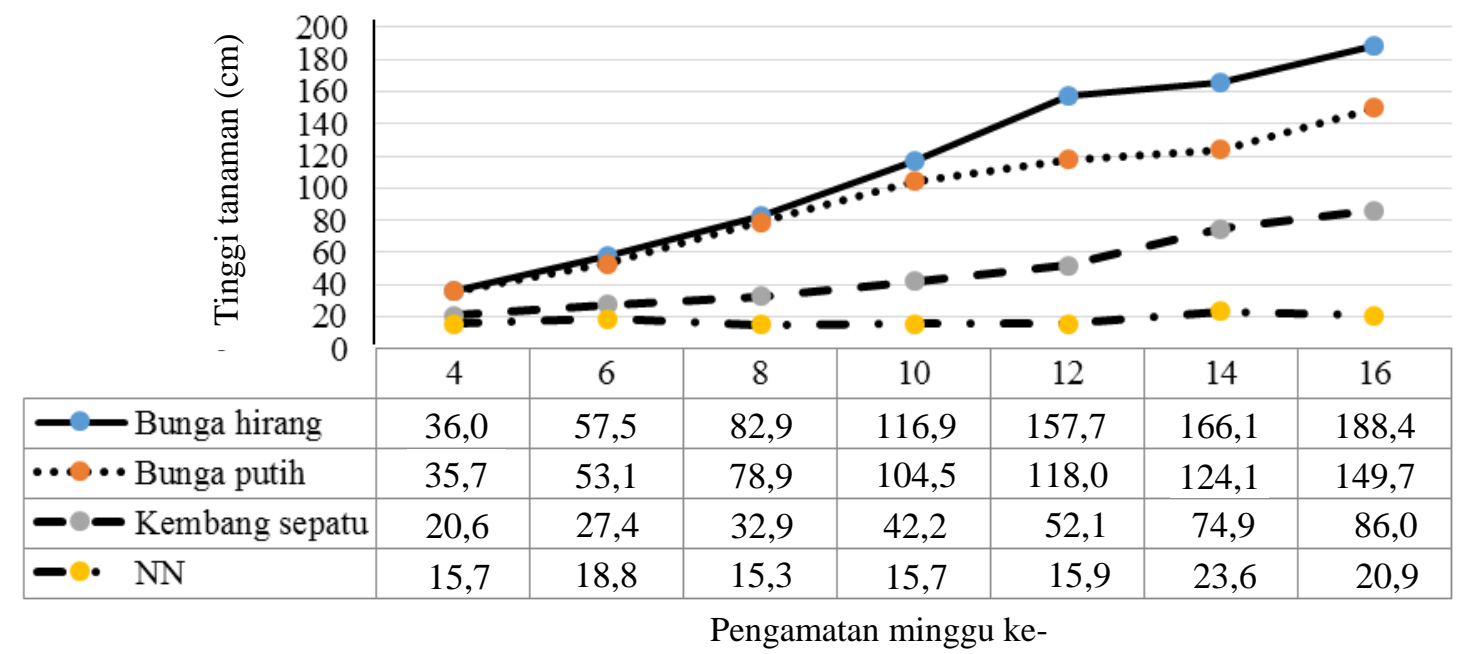

Gambar 2. Tinggi tanaman empat spesies TPT lokal pada tujuh kali pengamatan

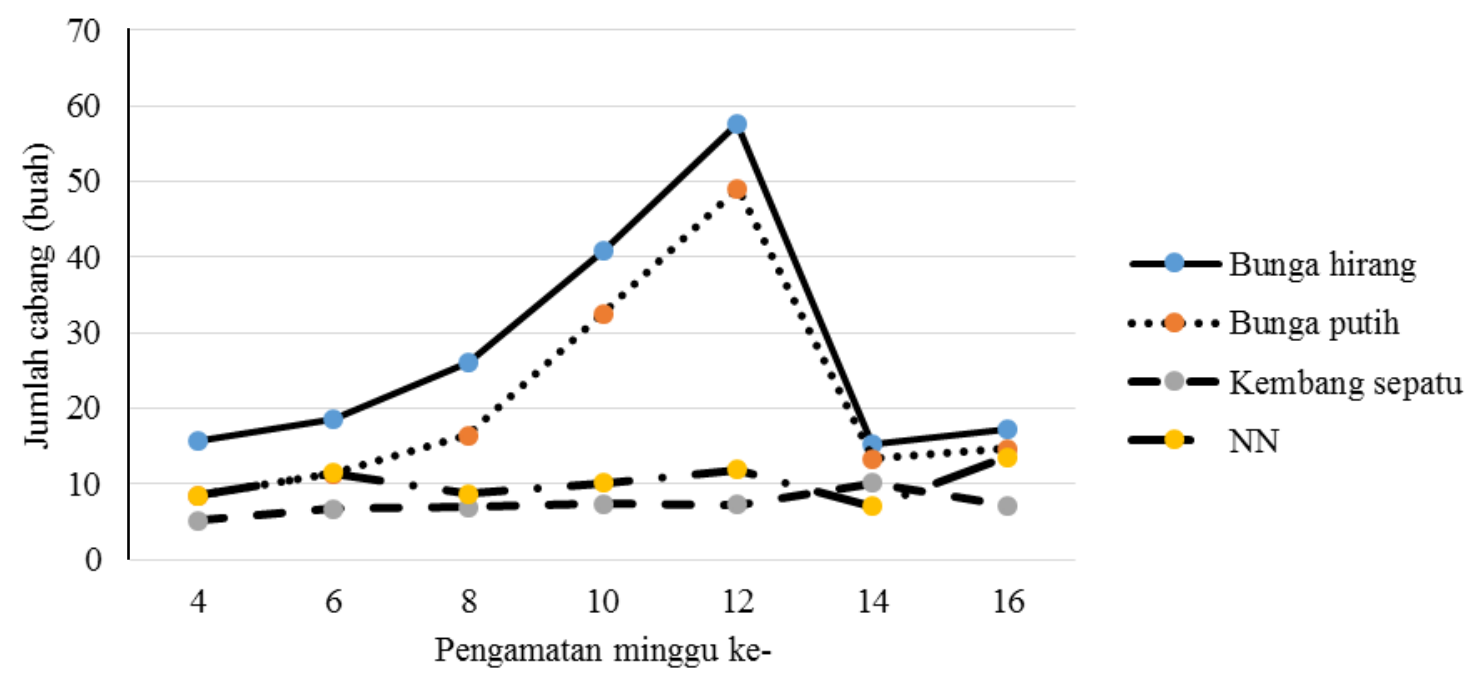

Gambar 3. Jumlah cabang empat spesies TPT lokal pada tujuh kali pengamatan

\section{Produksi tajuk}

Produksi tanaman pakan lokal pada dua kali pemanenan disajikan dalam Gambar 4. Hasil penelitian menunjukkan bahwa terdapat perbedaan nyata $(\mathrm{P}<0,05)$ produksi segar 
keempat spesies tanaman pakan lokal. Produksi bunga hirang (T. diversifolia) adalah yang tertinggi untuk dua kali pemanenan masing-masing 1.779,3 dan 2.146,7 g/tanaman untuk panen pertama dan kedua. yang diikuti oleh bunga putih masing-masing 664,7 dan 1.702 g/tanaman.

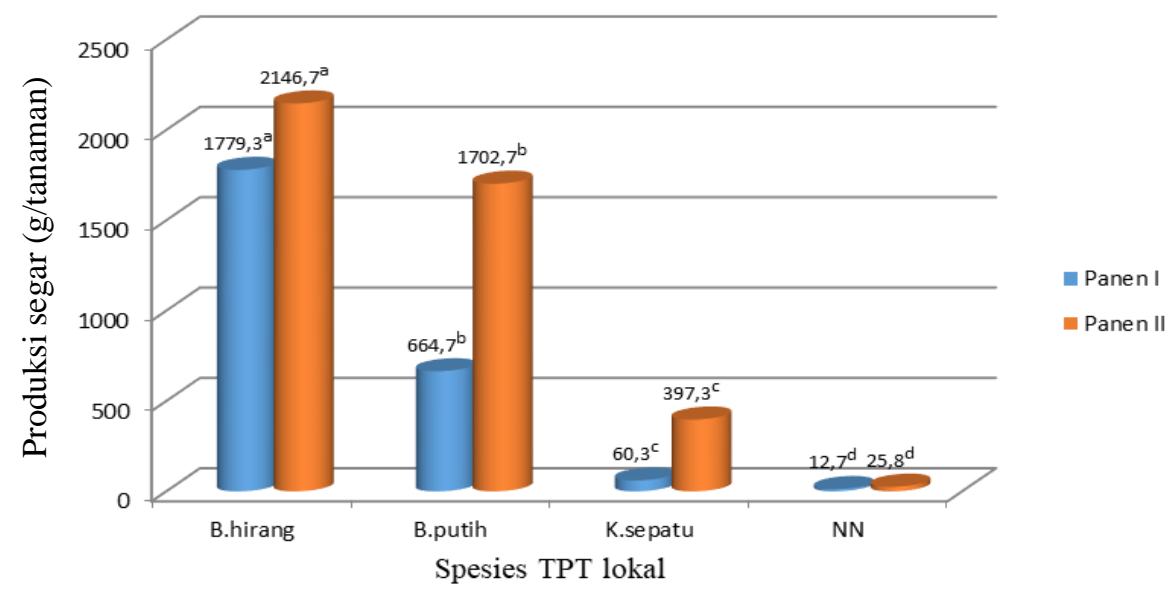

Gambar 4. Grafik produksi empat spesies TPT lokal pada dua kali pemanenan

Berdasarkan data produksi segar dan kadar air diperoleh rataan produksi bahan kering maupun produksi PK tertinggi dari dua kali pemanenan pada tanaman pakan bunga hirang (T. diversifolia) masing-masing sebesar 273,95 dan 52,6 g/tanaman/panen atau setara dengan 1,64 dan 0,32 kg/tanaman/tahun. Produksi BK T. diversifolia ini sedikit lebih rendah dibandingkan dengan hasil yang dilaporkan Feedipedia (2015) dengan produksi bahan kering mencapai $1,75-2,0 \mathrm{~kg} / \mathrm{m}^{2} /$ tahun namun lebih tinggi dibandingkan dengan hasil penelitian Desyrakhmawati et al. (2015) dengan rata-rata produksi 193,71 g/tanaman/panen. Produksi T. diversifolia ini masih menunjukkan peningkatan dengan produksi segar pada bulan Oktober dan Desember tahun 2016 masing-masing sebesar $2.337 \mathrm{dan} 1.975 \mathrm{~g} / \mathrm{tanaman} / \mathrm{panen}$.

Produksi terendah diperoleh pada tanaman NN (P. fruticosa (L) Harms) hanya 12,7 dan 25,8 g/tanaman. Bila diamati dari awal penanaman, pertumbuhan tanaman ini sangat lambat bahkan sebagian mengalami penurunan tinggi tanaman. Berdasarkan kondisi ini diduga tanaman ini lebih baik tumbuh pada kondisi yang ternaungi.

\section{Nilai nutrisi}

Nilai nutrisi yang diamati pada keempat spesies tanaman pakan lokal ini mencakup: bahan kering. bahan organik, PK, NDF, ADF dan energi kasar. Tanaman yang memiliki kandungan PK tertinggi pada pemanenan pertama adalah bunga putih ( $C$. surinamense L)sebesar 25,12\% diikuti oleh kembang sepatu (H. rosa-sinensis) sebesar 22,37\% (Tabel 3). Pada pemanenan kedua terjadi penurunan kandungan PK dan yang tertinggi diperoleh pada kembang sepatu sebesar 19,25\% yang diikuti oleh bunga hirang ( $T$. diversifolia) sebesar 18,88\%. Kandungan PK T. diversifolia ini berada pada kisaran seperti dilaporkan Anonimus (2015) yaitu sebesar 12 hingga 30\%, lebih tinggi dari yang ditemukan Sae et al. (2010) sebesar 14,53\% dan lebih tinggi dari hasil penelitian Togun et al. (2006) dengan kandungan PK sebesar 18,6\%. 
Tabel 3. Nilai nutrisi empat spesies TPT lokal pada dua kali pemanenan

\begin{tabular}{|c|c|c|c|c|c|c|}
\hline \multirow{3}{*}{ Nama TPT } & \multicolumn{6}{|c|}{ Nilai nutrisi } \\
\hline & Kadar air & Kadar abu & PK & NDF & $\mathrm{ADF}$ & \multirow{2}{*}{ Energi $(\mathrm{kkal} / \mathrm{kg})$} \\
\hline & \multicolumn{5}{|c|}{ 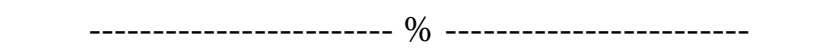 } & \\
\hline \multicolumn{7}{|c|}{ Panen I umur tiga bulan } \\
\hline Bunga putih & 83,60 & 13,80 & 25,12 & 42,76 & 29,36 & 4,5196 \\
\hline Bunga hirang & 85,41 & 12,94 & 19,56 & 40,42 & 30,15 & 4,0512 \\
\hline P. fruticosa & 87,04 & 11,80 & 11,54 & 36,27 & 23,95 & 4,7050 \\
\hline Kembang sepatu & 87,52 & 10,80 & 22,37 & 31,36 & 19,47 & 4,0011 \\
\hline \multicolumn{7}{|c|}{ Panen II umur lima bulan } \\
\hline Bunga putih & 87,28 & 12,87 & 18,19 & 44,48 & 36,30 & 3,9497 \\
\hline Bunga hirang & 86,57 & 12,65 & 18,88 & 35,15 & 29,10 & 4,4152 \\
\hline P. fruticosa & 87,92 & 10,92 & 11,20 & 37,45 & 25,41 & 4,4807 \\
\hline Kembang sepatu & 85,35 & 10,81 & 19,25 & 27,44 & 16,09 & 4,3114 \\
\hline
\end{tabular}

\section{KESIMPULAN}

Diantara empat spesies tanaman pakan lokal yang ditanam di kebun percobaan Lolitkambing. Bunga hirang (T. diversifolia) memiliki tinggi tanaman, jumlah cabang dan produksi tertinggi dibandingkan dengan tiga spesies lainnya $(C$. surinamense, $H$. rosasinensis dan $P$. fruticosa), namun bukan dengan nilai nutrisi terbaik. Kandungan PK tertinggi pada pemanenan pertama diperoleh pada $C$. surinamense yang diikuti oleh $H$. rosa-sinensis dan pada pemanenan kedua PK tertinggi diperoleh pada $H$. rosa-sinensis yang diikuti oleh $T$. diversifolia. Perlu diteliti pemanfaatan tanaman pakan lokal ini untuk kambing.

\section{DAFTAR PUSTAKA}

Anonimus. 2015. Thitonia diversifolia sebagai sumber pupuk hijau [Internet]. [cited 5 Mei 2015] Available from: https://www.google.co.id/search?q=kirinyuh\&source=lnms\&sa=X\&ved=0ah UKEwikqKal1-rWAhWBw5QKHX_3ASYQ_AUICSgA\&biw=1920\&bih=949\&dpr=1

Anonimus. 2017. Clibadium surinamense. Useful Tropical Plants [Internet]. [cited 3 Februari 2017]. Available from: http://tropical.theferns.info/viewtropical.php?id=Clibadium+ surinamense

AOAC. 1990. Official methods of analysis. In: Helrich K, editor. $15^{\text {th }}$ Ed. Virginia (US): Association of Official Analytical Chemist. Inc. Arlington.

Balitbangtan. 2004. International treaty on plant genetic resources for food and agriculture (ITPGR/FA). Jakarta (Indonesia): Balitbangtan.

Desyrakhmawati L, Melati M, Suwarto, Hartatik W. 2015. Pertumbuhan Tithonia diversifolia dengan dosis pupuk kandang dan jarak tanam yang berbeda. J Agron Indonesia. 43:72-80.

Feedipedia. 2014. Mexican sunflower (Tithonia diversifolia). Feedipedia [Internet]. [cited 13 Februari 2017]. Available from: http://www.feedipedia.org/node/15645

Goering HK, Van Soest PJ. 1970. Forage fiber analyses (apparatus, reagents, procedures and some application). Washington DC (US): USDA. 
Gomez KA, Gomez AA. 1995. Prosedur statistik untuk penelitian pertanian. Dalam: Sjamsuddin E, Baharsjah JS, penerjemah. Jakarta (Indonesia): UI Press.

Sae NV, Mui NT, Binh DV. 2010. Biomass production of Tithonia diversifolia (wild sunflower), soil improvement on sloping land and uses as high protein foliage for feeding goats. Livest Rur Develop. 22.

SAS. 1987. SAS User's Guide: Statistic. $6^{\text {th }}$ ed. Cary NC (US): SAS Institute Inc.

Steel RGD, Torrie JH. 1995. Prinsip dan prosedur statistika: Suatu pendekatan biometrik. Dalam: Sumantri B, penerjemah. Jakarta (Indonesia): Gramedia Pustaka Utama.

Tarigan A, Sirait J, Ginting S. 2013. Produksi dan komposisi nutrisi Indigofera sp pada intensitas pemotongan dan jarak tanam yang berbeda di dataran tinggi dengan curah hujan sedang. Dalam: Purwanti ND, Saepulloh M, Iskandar S, Anggraeni A, PriyantiA, Wiedosari E, Yulistiani D, Inounu I, Bahri S, Puastuti W, penyunting. Inovasi Teknologi Peternakan dan Veteriner Berbasis Sumber Daya Lokal yang Adaptif dan Mitigatif terhadap Perubahan Iklim. Prosiding Seminar Nasional Teknologi Peternakan dan Veteriner. Medan, 3-5 September 2013. Bogor (Indonesia): Puslitbangnak. hlm. 441-448.

Togun VA. Farinu GO. Olobanji. RO. 2006. Feeding graded levels of wild sunflower (Tithonia diversifolia Hemsl A Gray) meal in replacement of maize at pre-pubertal age, negative impacts on growth and morphometric characteristics of the genitalia of Anak 2000 Broiler Cocks on their pubertal age. World Appl Sci J. 1:115-121.

USDA. 2017. Plant classification. United States Departement of Agriculture [Internet]. [cited 3 Februari 2017]. Available from: https://plants.usda.gov/core/profile?symbol=HIRO3\#

Van Soest PJ, Robertson JB, Lewis BA. 1991. Methods for dietary fiber. neutral detergent fiber, and non-starch polysaccharides in relation to animal nutrition. J Dairy Sci.74:3583-3597.

Wikipedia. 2017a. Tithonia diversifolia. Wikipedia [Internet]. [cited 3 Februari 2017]. Available from: https://en.wikipedia.org/wiki/Tithonia_diversifolia

Wikipedia. 2017b. Hibiscus rosa-sinensis. Wikipedia [Internet]. [cited 3 Februari 2017]. Available from: https://en.wikipedia.org/wiki/Hibiscus_rosa-sinensis

Wikipedia. 2017c. Polyscias fruticosa. Wikipedia [Internet]. [cited 3 Februari 2017]. Available from: https://en.wikipedia.org/wiki/Polyscias_fruticosa

\section{DISKUSI}

\section{Pertanyaan}

Kenapa nilai nutrisi tanaman pakan lokal berbeda setiap pemotongan dan apakah sudah diberikan kepada ternak?

\section{Jawaban}

Waktu pemotongan menentukan umur tanaman yang akan menentukan nilai nutrisi tanaman tersebut. Tanaman ini belum diberikan kepada ternak. 